\title{
Identification and characterization of a new true lipase isolated through metagenomic approach
}

\author{
Arnaldo Glogauer,', Viviane P Martini², Helisson Faoro1', Gustavo H Couto', Marcelo Müller-Santos', \\ Rose A Monteiro', David A Mitchell', Emanuel M de Souza', Fabio O Pedrosa ${ }^{1}$ and Nadia Krieger ${ }^{2 *}$
}

\begin{abstract}
Background: Metagenomics, the application of molecular genomics to consortia of non-cultivated microbes, has the potential to have a substantial impact on the search for novel industrial enzymes such as esterases (carboxyl ester hydrolases, EC 3.1.1.1) and lipases (triacylglycerol lipases, EC 3.1.1.3). In the current work, a novel lipase gene was identified from a fosmid metagenomic library constructed with the "prokaryotic-enriched" DNA from a fatcontaminated soil collected from a wastewater treatment plant.
\end{abstract}

Results: In preliminary screening on agar containing 1\% tributyrin, 2661 of the approximately 500,000 clones in the metagenomic library showed activity. Of these, 127 showed activity on agar containing $1 \%$ tricaprylin, while 32 were shown to be true lipase producers through screening on agar containing $1 \%$ triolein. The clone with the largest halo was further characterized. Its lipase gene showed $72 \%$ identity to a putative lipase of Yersinia enterocolitica subsp. palearctica Y11. The lipase, named LipC12, belongs to family 1.1 of bacterial lipases, has a chaperone-independent folding, does not possess disulfide bridges and is calcium ion dependent. It is stable from pH 6 to 11 and has activity from pH 4.5 to 10, with higher activities at alkaline pH values. LipC12 is stable up to 3.7 $\mathrm{M} \mathrm{NaCl}$ and from 20 to $50^{\circ} \mathrm{C}$, with maximum activity at $30^{\circ} \mathrm{C}$ over a $1 \mathrm{~h}$ incubation. The pure enzyme has specific activities of $1722 \mathrm{U} / \mathrm{mg}$ and $1767 \mathrm{U} / \mathrm{mg}$ against olive oil and pig fat, respectively. Moreover, it is highly stable in organic solvents at $15 \%$ and $30 \%(\mathrm{~V} / \mathrm{v})$.

Conclusions: The combination of the use of a fat-contaminated soil, enrichment of prokaryotic DNA and a threestep screening strategy led to a high number of lipase-producing clones in the metagenomic library. The most notable properties of the new lipase that was isolated and characterized were a high specific activity against long chain triacylglycerols, activity and stability over a wide range of $\mathrm{pH}$ values, good thermal stability and stability in water-miscible organic solvents and at high salt concentrations. These characteristics suggest that this lipase has potential to perform well in biocatalytic processes, such as for hydrolysis and synthesis reactions involving longchain triacylglycerols and fatty acid esters.

\section{Background}

Lipases (triacylglycerol lipases, EC 3.1.1.3) are enzymes that act on ester bonds, either hydrolyzing or synthesizing them, depending on the amount of water in the reaction medium [1-3]. True lipases attack triacylglycerols that contain long-chain fatty acids. They are important biocatalysts for various biotechnological applications due to their useful features, such as stability in organic solvents, broad substrate specificity, stereoselectivity and regioselectivity [4].

\footnotetext{
* Correspondence: nkrieger@ufpr.br

${ }^{2}$ Department of Chemistry, Federal University of Paraná, Curitiba/PR, Brazil

Full list of author information is available at the end of the article
}

Although lipases can be obtained from plants and animals, microbial lipases possess useful features such as high yield and low production cost, diversity in catalytic activities, amenability to genetic manipulation, stability in organic solvents and broad substrate specificity [5]. While a large number of different lipases have been discovered and commercialized [4], new lipases with better characteristics are desirable, such as high activity and stability in non-aqueous media, which are useful for biodiesel production through transesterification [6-8], regiospecificity for the modification of oils and fats to produce specific-structured lipids $[9,10]$ and stability

\section{Biomed Central}


under alkaline conditions and in the presence of surfactants for use in detergent formulations [11].

The vast majority of lipases that are currently used industrially were isolated from cultivated microbes [12], however, in more recent times, it has become difficult to obtain truly different lipases by this method. To overcome this limitation, molecular biology and protein engineering strategies have been used, such as directed evolution [13], rational design [14,15] and metagenomics [16-20].

The metagenomics approach, the application of molecular genomics to consortia of non-cultivated microbes, has a substantial impact on the search for novel industrial enzymes due to the vast diversity of genetic material analyzed [21-24]. The advantage of metagenomics can be summarized in numerical terms since more than 99\% of microorganisms are not amenable to cultivation [25], either due to their required growth conditions being unknown or to their need to grow within a microbial consortium.

Although various esterases and so-called lipases have been isolated through the metagenomic approach over the last decade [26-31], relatively few papers report true lipases [32-37]. Several of the enzymes obtained have activity against medium-chain triacylglycerols, longchain monoacyl glycerols or long-chain nitrophenyl acyl esters, but do not have activity against triacylglycerols that contain long-chain fatty acids, such as vegetable oils or animal fats. For example, the so-called PLP and Est1 lipases, both of which were isolated through the metagenomic approach [38], and Sulfolobus acidocaldarius lipase [39] are active against $p$-nitrophenyl palmitate $(p \mathrm{NPP})$ but not against trioleoylglycerol. As a result, these so-called lipases simply cannot be considered as true lipases.

As new lipases with high activity against oils and fats have industrial potential, in the current work we used three strategies in combination in an attempt to improve the chances of obtaining a true lipase through the metagenomic approach, namely (i) a high-fat soil as the original source of the DNA, (ii) a prokaryotic DNA enrichment step and (iii) a three-stage screening strategy in which the third stage tested for true lipase activity.

\section{Results}

Sample collection, metagenomic library construction and activity screening

Samples were collected from the bank of an anaerobic lagoon of the wastewater treatment plant of a meat packing and dairy industry. The effluent from the plant has a high animal fat content that contaminates the soil surrounding the lagoon, presumably favoring the development of a microbiota capable of degrading fats.
Consequently, this soil sample should be enriched with lipase genes.

The generated metagenomic library has approximately 500,000 clones. The screening strategy used involved the use of LB agar with two or more different types of triacylglycerols to differentiate lipases from esterases $[19,40]$. Thus, the 2,661 clones that showed activity against tributyrin (Figure 1a) were screened on LB agar containing $1 \%(\mathrm{v} / \mathrm{v})$ tricaprylin and 127 clones with activity were selected. In order to identify true-lipase producers, these clones were screened on LB agar containing $1 \%(\mathrm{v} / \mathrm{v})$ triolein, resulting in 32 with activity. Three clones, FosC12, FosE6 and FosH10, which showed the largest hydrolysis halos on triolein (Figure 1b), were selected for further characterization.

\section{Sequencing of LipC12 and preliminary sequence analysis}

The fosmids FosC12, FosE6 and FosH10 were fragmented by nebulization and subcloned into the pUC18 vector, producing three subclone libraries. The inserts of subclones that expressed lipolytic activity on tributyrin agar plates were fully sequenced and sequence comparison revealed that all three fosmids contained the same lipase gene (result not shown). The lipase gene from fosmid FosC12, denominated lipC12, was selected for further characterization. Amino acid sequence alignment showed that lipC12 codes for a lipase having $72 \%$ identity to the putative lipase of Yersinia enterocolitica subsp. palearctica Y11 [GenBank:CBY26912]. Neither transmembrane domains nor a signal peptide were identified and LipC12 was predicted to be a soluble protein. No chaperone sequence gene located close to the lipC12 gene was found in the lipC12 contig, suggesting that LipC12 has a chaperone-independent folding.

The lipC12 gene was amplified and cloned into pET$28 \mathrm{a}(+)$ and transformed into E. coli BL21(DE3) cells to express the $\mathrm{N}$-terminal (His)6-tagged protein. No mutation occurred in the lipC12 sequence in the course of these cloning procedures.

\section{Overexpression and purification of LipC12 lipase}

The overexpressed LipC12 has a molecular weight of 33 395.8 $\mathrm{Da}$ and was in the soluble fraction, as judged by SDS-PAGE (result not shown). BL21(DE3) cells carrying the pET28a-lipC12 plasmid were induced at $20^{\circ} \mathrm{C}$ for 16 $\mathrm{h}$ to maximize the protein yield. LipC12 was purified in one step using a HiTrap Chelating HP affinity column, as shown by SDS-PAGE of eluted fractions (Figure 1c). The eluted fractions containing LipC12 were combined and dialyzed against Tris- $\mathrm{HCl}$ buffer to concentrate the protein solution and eliminate imidazol. Glycerol at 50\% $(\mathrm{w} / \mathrm{v})$ final concentration was added to the protein storage buffer as a cryoprotective agent. The enzyme 

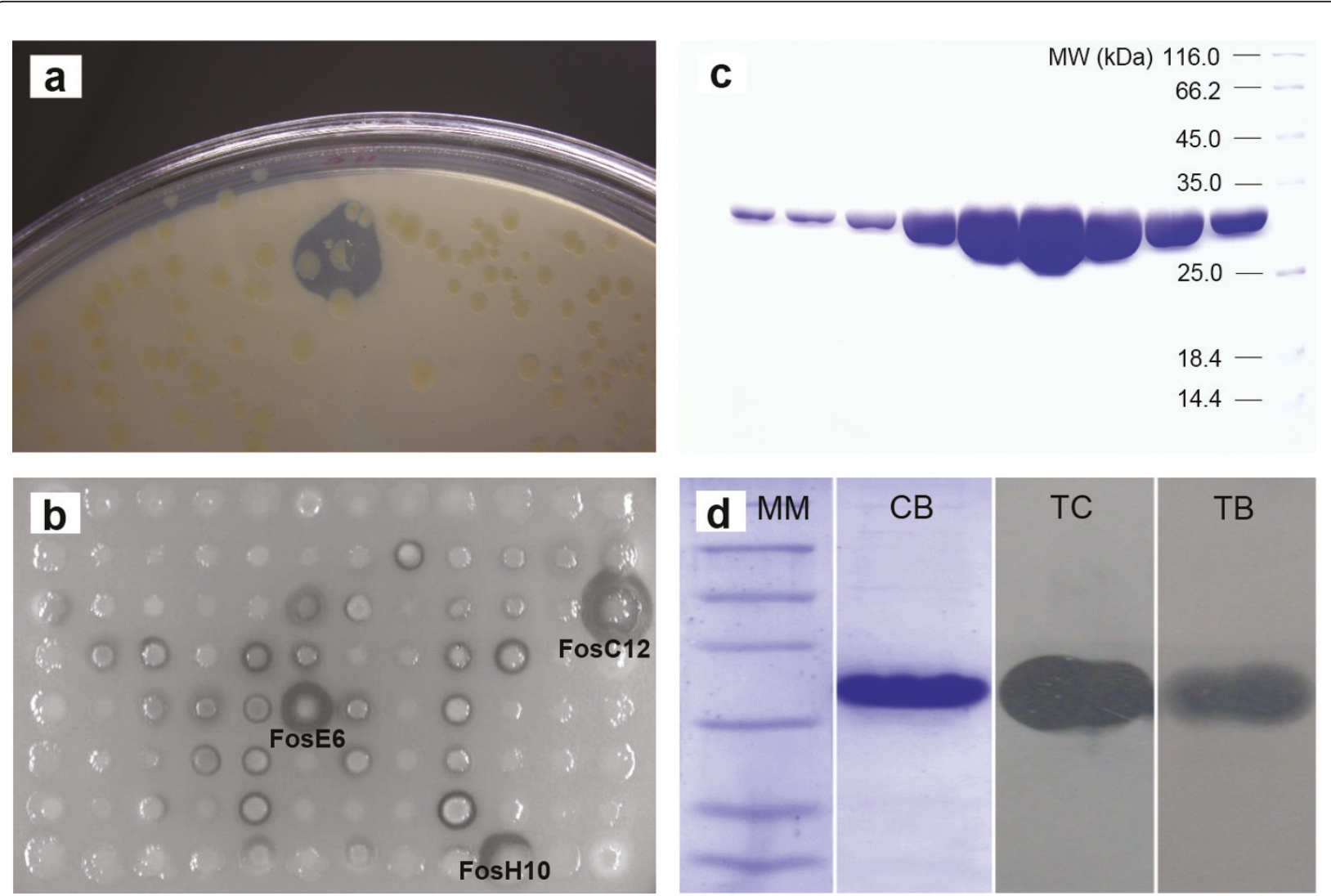

Figure 1 Isolation, purification and identification of LipC12. (a) Identification of a lipolytic clone that formed a hydrolysis halo in the tributyrin plate assay. (b) Hydrolysis halos formed by lipase-producing clones in the triolein plate assay. FosC12, FosE6 and FosH10 showed the largest hydrolysis halos and were chosen for sequencing. (c) SDS-PAGE of fractions of His-tagged LipC12 eluted from the affinity chromatography column. (d) SDS-PAGE and zymogram analyses of LipC12. The lanes correspond to molecular marker (MM), coomassie blue staining (CB) and lipolytic activity of LipC12 on the SDS-PAGE gel, using tricaprylin (TC) and tributyrin (TB) as substrates.

preparation $(5.78 \mu \mathrm{g} / \mu \mathrm{L})$ was more than $97 \%$ pure as judged by densitometric analysis of SDS-PAGE.

\section{Zymogram and mass spectrometry analysis}

Zymographic analysis was carried out using tributyrin and tricaprylin as substrates. The clear bands that were obtained in the $30 \mathrm{kDa}$ region using both substrates reveal that the purified enzyme was active, with a larger clearing zone occurring in the tricaprylin gel than in the tributyrin gel (Figure 1d). MALDI-TOF/MS confirmed that the purified enzyme is LipC12, with $68.4 \%$ of sequence coverage (result not shown). Together, these results confirm the identity of the purified protein.

\section{Protein sequence analysis}

LipC12 has 293 amino acids and an identity of $72 \%$ with the putative lipases of Yersinia enterocolitica subsp. palearctica Y11 [GenBank:CBY26912] and of Yersinia enterocolitica subsp. enterocolitica 8081 [GenBank: YE1842]. The domain analysis carried out using Pfam showed that the enzyme probably has a type I $\alpha / \beta$ - hydrolase fold [41] between residues 23 and 227. Phylogenetic analysis showed that the most similar enzymes to LipC12 are those from enterobacteria, such as Yersinia sp., Proteus sp. and Arsenophonus sp. (Figure 2). Among the lipases that have known 3D structure, LipC12 possesses $47 \%, 41 \%$ and $41 \%$ of identity with lipases of Pseudomonas aeruginosa [PDB:1EX9A], Burkholderia glumae [PDB:2ES4B] and Burkholderia cepacia [PDB:1OILA], respectively.

The LipC12 catalytic triad is predicted to be formed by $\mathrm{Ser}^{83}, \mathrm{Asp}^{238}$ and $\mathrm{His}^{260}$ (Figure 3) and the nucleophilic $\mathrm{Ser}^{83}$ residue appears in the conserved pentapeptide Gly-X-Ser-X-Gly [41]. Two Asp residues of LipC12 $\left(\mathrm{Asp}^{217}\right.$ and $\mathrm{Asp}^{262}$ ) form a calcium binding pocket that is conserved in lipases of subfamilies I.1 and I.2 [42,43]. LipC12 contains only one Cys residue, similar to the lipases of Pseudomonas fragi [GenBank:CAC07191], Proteus vulgaris [GenBank:AAB01071, GenBank: ACM67042], Yersinia enterocolitica [GenBank: CBY26912, GenBank:YE1842] and Yersinia mollaretti [GenBank:ZP_04641632], and therefore does not form a 


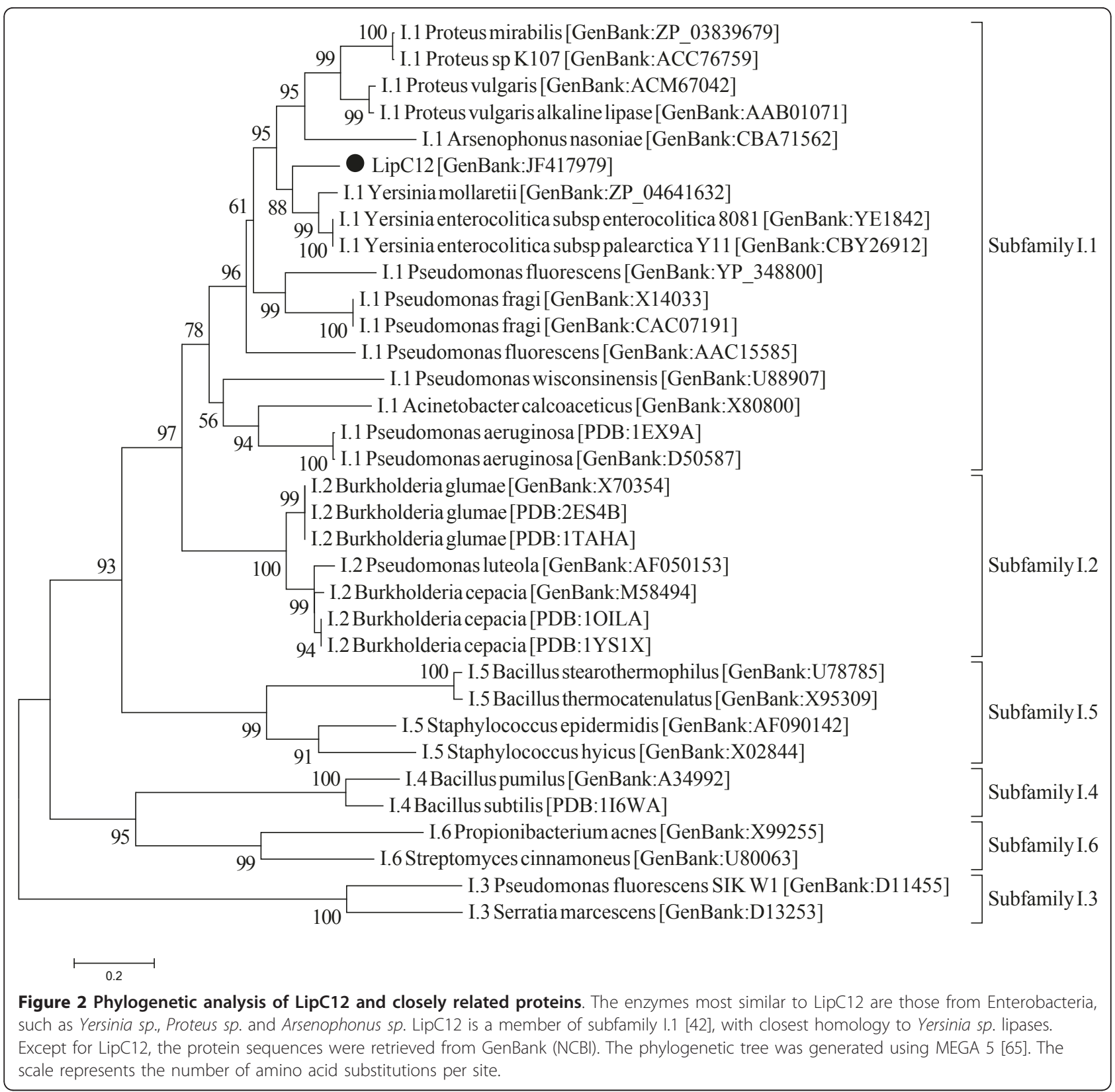

disulfide bridge as found in the lipases of Pseudomonas aeruginosa [PDB:1EX9A], Burkholderia glumae [PDB:2ES4B] and Burkholderia cepacia [PDB:1OILA]. The expression of lipases belonging to subfamilies I.1 and I.2 in an active form often depends on a chaperone protein named lipase-specific foldase, Lif, that is usually encoded in an operon with its cognate lipase $[1,42]$. This chaperone is absent in the LipC12 operon and has not yet been found or described for the lipases of subfamily I.1 that have the highest identities with LipC12, as is the case of Yersinia enterocolitica [GenBank: CBY26912, GenBank:YE1842], Yersinia mollaretti [GenBank:ZP_04641632], Proteus vulgaris [GenBank:
AAB01071, GenBank:ACM67042] and Pseudomonas fragi [GenBank:CAC07191] lipases. Thus, it is possible to conclude that LipC12 belongs to subfamily I.1.

\section{Spectrophotometric determinations of lipase activity using $p$ NP substrates}

Effect of chelating agents and metal ions on LipC12 activity LipC12 activity decreases in the presence of the chelating agents EDTA and EGTA, more intensely so for EGTA, which preferentially binds calcium (Table 1). This result suggested that calcium might be a preferred cofactor of LipC12. To check whether LipC12 has a preference for binding $\mathrm{Ca}^{2+}$, an experiment was done in 


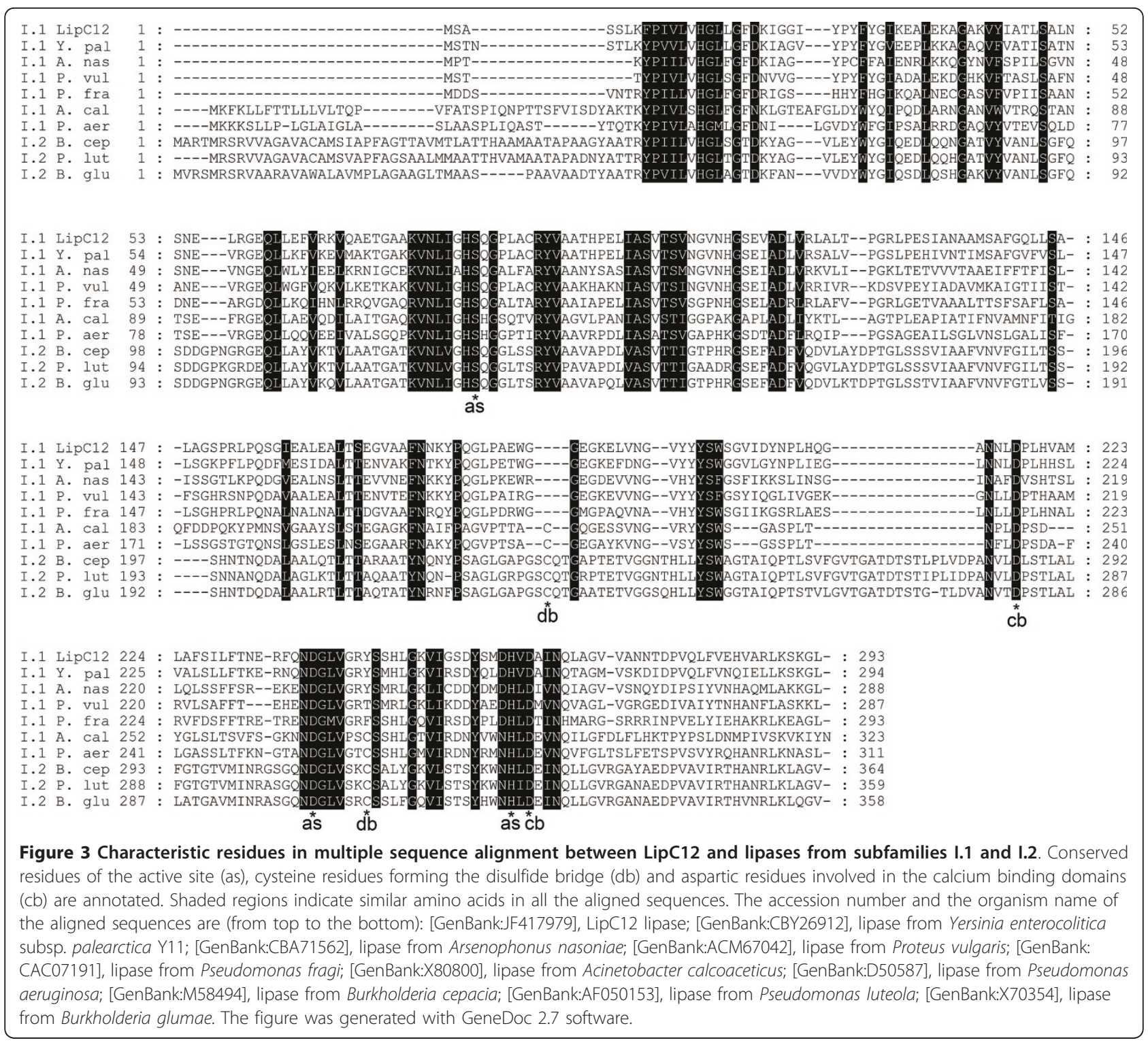

which the metal was depleted by EDTA prior to the testing of the activity in the presence of excess metal. Maximum activity was achieved with the addition of $\mathrm{Ca}^{2+}$, but activity was also restored at lower levels in the presence of other divalent cations, such as $\mathrm{Cu}^{2+}, \mathrm{Co}^{2+}$, $\mathrm{Mn}^{2+}$ and $\mathrm{Ni}^{2+}$. This result, when taken together with the presence of a putative calcium binding pocket, is strong evidence for LipC12 being calcium ion dependent. In experiments undertaken without a prior chelation step, in which the calcium binding pocket was presumably occupied by a calcium ion, the presence of $1 \mathrm{mM}$ of monovalent cations $\left(\mathrm{Rb}^{+}, \mathrm{K}^{+}, \mathrm{Cs}^{+}, \mathrm{Na}^{+}\right.$or $\left.\mathrm{Li}^{+}\right)$ enhanced LipC12 activity (Table 1 ). The most likely explanation for this is that the presence of these cations improves the solubility of $p$ NPP within the emulsion. Evidence of this increase in solubility is given by the fact that at $1.5 \mathrm{M} \mathrm{NaCl}$ the $p \mathrm{NPP}$ emulsion remained transparent even without heating.

\section{Effect of anions on the LipC12 activity}

The effect of anions on LipC12 activity was also tested. All anions used were added in the form of sodium salts and none showed a significant effect on activity at 1 $\mathrm{mM}$ (Table 1). However, $\mathrm{PO}_{4}{ }^{3-}$ at $10 \mathrm{mM}$ decreased the enzyme activity by about $30 \%$, suggesting that $\mathrm{PO}_{4}{ }^{3-}$ competes with LipC12 for $\mathrm{Ca}^{2+}$.

\section{LipC12 enantioselectivity and substrate specificity against pNP esters}

LipC12 is most active against longer-chain nitrophenyl acyl esters, with relative activities above $75 \%$ for evennumbered acyl chain lengths from C10:0 to C16:0 (Table 1). For shorter acyl chain lengths ( $\mathrm{C} 2: 0$ to $\mathrm{C} 6: 0)$, the relative activities are below $35 \%$. This preference for longer 
Table 1 Effect of some additives, substrate chain length and temperature on the activity of LipC12

\begin{tabular}{|c|c|c|c|c|c|}
\hline Variable & $\begin{array}{l}\text { Relative } \\
\text { activity (\%) }\end{array}$ & Variable & $\begin{array}{l}\text { Relative } \\
\text { activity (\%) }\end{array}$ & Variable & $\begin{array}{l}\text { Relative } \\
\text { activity (\%) }\end{array}$ \\
\hline \multicolumn{2}{|c|}{ Cation (1 mM) after EDTA chelation ${ }^{a}$} & \multicolumn{2}{|c|}{ Cation (1 mM) without EDTA chelation } & \multicolumn{2}{|l|}{ Substrate specificity } \\
\hline None & $<0.5$ & None $e^{\mathrm{b}}$ & $100.0 \pm 3.4$ & pNP palmitate $(C 16: 0)^{b, d}$ & $100.0 \pm 2.2$ \\
\hline $\mathrm{CaCl}_{2}^{\mathrm{b}}$ & $100.0 \pm 1.2$ & $\mathrm{RbCl}$ & $128.4 \pm 2.3$ & pNP myristate (C14:0) & $75.4 \pm 1.7$ \\
\hline $\mathrm{CuCl}_{2}$ & $59.3 \pm 0.3$ & $\mathrm{KCl}$ & $121.8 \pm 4.6$ & pNP dodecanoate (C12:0) & $90.0 \pm 4.9$ \\
\hline $\mathrm{Al}_{2}\left(\mathrm{SO}_{4}\right)_{3}$ & $59.2 \pm 0.1$ & $\mathrm{CsCl}$ & $104.1 \pm 4.7$ & pNP decanoate (C10:0) & $83.2 \pm 1.7$ \\
\hline $\mathrm{CoCl}_{2}$ & $54.9 \pm 0.6$ & $\mathrm{NaCl}$ & $94.3 \pm 4.4$ & pNP caproate (C6:0) & $29.3 \pm 0.7$ \\
\hline $\mathrm{MnCl}_{2}$ & $54.9 \pm 1.2$ & $\mathrm{LiCl}$ & $92.7 \pm 2.3$ & pNP valerate $(C 5: 0)$ & $34.3 \pm 2.1$ \\
\hline $\mathrm{NiCl}_{2}$ & $53.3 \pm 0.6$ & $\mathrm{Ba}(\mathrm{Ac})_{2}$ & $85.4 \pm 5.3$ & pNP butyrate (C4:0) & $25.6 \pm 0.8$ \\
\hline $\mathrm{FeSO}_{4}$ & $37.4 \pm 0.9$ & $\mathrm{CaCl}_{2}$ & $73.4 \pm 4.2$ & pNP acetate (C2:0) & $1.9 \pm 0.2$ \\
\hline $\mathrm{Pb}(\mathrm{Ac})_{2}$ & $33.9 \pm 0.2$ & $\mathrm{SnCl}_{2}$ & $67.6 \pm 3.4$ & Optimal temperature ${ }^{e}$ & \\
\hline $\mathrm{CdSO}_{4}$ & $32.7 \pm 0.3$ & $\mathrm{NiCl}_{2}$ & $66.0 \pm 1.0$ & $9.9^{\circ} \mathrm{C}$ & $38.4 \pm 6.4$ \\
\hline $\mathrm{HgCl}_{2}$ & $29.5 \pm 0.9$ & $\mathrm{MgCl}_{2}$ & $64.5 \pm 1.9$ & $20.5^{\circ} \mathrm{C}$ & $93.8 \pm 6.6$ \\
\hline $\mathrm{MgCl}_{2}$ & $4.0 \pm 0.1$ & $\mathrm{HgCl}_{2}$ & $62.3 \pm 1.3$ & $30.0^{\circ} \mathrm{C}^{\mathrm{b}}$ & $100.0 \pm 5.1$ \\
\hline $\mathrm{AgNO}_{3}$ & $0.9 \pm 0.2$ & $\mathrm{CoCl}_{2}$ & $53.8 \pm 0.7$ & $40.0^{\circ} \mathrm{C}$ & $37.7 \pm 7.7$ \\
\hline $\mathrm{Ba}(\mathrm{AC})_{2}$ & $0.8 \pm 0.1$ & $\mathrm{CuCl}_{2}$ & $52.4 \pm 0.9$ & $50.7^{\circ} \mathrm{C}$ & $14.8 \pm 3.5$ \\
\hline $\mathrm{KCl}$ & $<0.5$ & $\mathrm{CdSO}_{4}$ & $49.8 \pm 2.3$ & $60.6^{\circ} \mathrm{C}$ & $11.1 \pm 3.6$ \\
\hline $\mathrm{ZnCl}_{2}$ & $<0.5$ & $\mathrm{FeCl}_{3}$ & $48.8 \pm 5.3$ & Sodium chloride & \\
\hline $\mathrm{SnCl}_{2}$ & $<0.5$ & $\mathrm{MnCl}_{2}$ & $47.1 \pm 1.7$ & None ${ }^{b}$ & $100.0 \pm 2.9$ \\
\hline $\mathrm{LiCl}$ & $<0.5$ & $\mathrm{ZnCl}_{2}$ & $44.5 \pm 2.9$ & $0.01 \mathrm{M}$ & $109.4 \pm 4.5$ \\
\hline $\mathrm{RbCl}$ & $<0.5$ & $\mathrm{Al}_{2}\left(\mathrm{SO}_{4}\right)_{3}$ & $44.8 \pm 1.3$ & $0.05 \mathrm{M}$ & $121.8 \pm 2.0$ \\
\hline $\mathrm{CsCl}$ & $<0.5$ & $\mathrm{FeSO}_{4}$ & $33.4 \pm 0.5$ & $0.1 \mathrm{M}$ & $126.0 \pm 3.2$ \\
\hline $\mathrm{NaCl}$ & $<0.5$ & $\mathrm{~Pb}(\mathrm{Ac})_{2}$ & $26.9 \pm 0.4$ & $0.2 \mathrm{M}$ & $148.8 \pm 4.1$ \\
\hline $\mathrm{FeCl}_{3}$ & $<0.5$ & $\mathrm{AgNO}_{3}$ & $8.2 \pm 0.4$ & $0.5 \mathrm{M}$ & $349.4 \pm 26.1$ \\
\hline Anion ${ }^{c}(1 \mathrm{mM})$ & & Anion $^{c}(10 \mathrm{mM})$ & & $1.0 \mathrm{M}$ & $1346.5 \pm 38.2$ \\
\hline None $e^{b}$ & $100.0 \pm 4.5$ & None $e^{b}$ & $100.0 \pm 1.4$ & $1.5 \mathrm{M}$ & $1501.5 \pm 74.6$ \\
\hline $\mathrm{CH}_{3} \mathrm{COO}-$ & $108.4 \pm 7.8$ & $\mathrm{SO}_{4}^{2}-$ & $110.4 \pm 0.9$ & $2.0 \mathrm{M}$ & $1333.5 \pm 95.4$ \\
\hline $\mathrm{NO}_{3}^{-}$ & $102.6 \pm 2.6$ & $\mathrm{SO}_{3}{ }^{2-}$ & $109.1 \pm 1.0$ & $2.5 \mathrm{M}$ & $37.2 \pm 7.5$ \\
\hline $\mathrm{SO}_{4}^{2}-$ & $99.3 \pm 3.4$ & $\mathrm{CH}_{3} \mathrm{COO}-$ & $108.4 \pm 2.2$ & $3.0 \mathrm{M}$ & $114.3 \pm 1.6$ \\
\hline $\mathrm{Cl}-$ & $97.4 \pm 5.4$ & $\mathrm{Cl}-$ & $104.5 \pm 0.8$ & $3.5 \mathrm{M}$ & $164.4 \pm 8.1$ \\
\hline $\mathrm{SO}_{3}{ }^{2}-$ & $96.9 \pm 3.5$ & $\mathrm{NO}_{3}^{-}$ & $102.2 \pm 2.7$ & $4.0 \mathrm{M}$ & $170.9 \pm 1.7$ \\
\hline $\mathrm{PO}_{4}{ }^{3}-$ & $93.2 \pm 6.2$ & $\mathrm{PO}_{4}{ }^{3}-$ & $68.0 \pm 1.4$ & Modifying reagent (1 mM) & \\
\hline Detergent (0.1\%) & & Detergent (1\%) & & None ${ }^{\mathrm{b}}$ & $100.0 \pm 0.6$ \\
\hline None $e^{b}$ & $100.0 \pm 3.7$ & None $e^{b}$ & $100.0 \pm 1.2$ & PMSF & $13.1 \pm 1.2$ \\
\hline$C T A B$ & $175.0 \pm 3.7$ & Triton $X-100$ & $34.3 \pm 0.3$ & DEPC & $35.4 \pm 0.4$ \\
\hline NLS & $130.5 \pm 0.1$ & NP40 & $29.0 \pm 0.5$ & Chelating agent $(10 \mathrm{mM})$ & \\
\hline Triton X-100 & $114.1 \pm 3.6$ & NLS & $16.9 \pm 0.4$ & None $e^{b}$ & $100.0 \pm 1.5$ \\
\hline NP40 & $102.8 \pm 2.6$ & Tween 40 & $15.4 \pm 0.7$ & EDTA & $50.0 \pm 2.4$ \\
\hline Tween 20 & $56.4 \pm 1.8$ & Tween 20 & $15.4 \pm 0.2$ & EGTA & $22.4 \pm 0.6$ \\
\hline SDS & $50.7 \pm 2.4$ & Tween 80 & $12.9 \pm 0.3$ & Emulsifying agent & \\
\hline Tween 40 & $38.6 \pm 1.0$ & CTAB & $12.0 \pm 0.7$ & None $e^{b}$ & $100.0 \pm 2.2$ \\
\hline Tween 80 & $32.6 \pm 0.3$ & SDS & $8.8 \pm 0.2$ & Gum arabic $(0.5 \%)$ & $186.5 \pm 1.3$ \\
\hline
\end{tabular}

All measurements were performed using the $p$ NPP method. Standard errors of the mean values are shown. ${ }^{\text {a }}$ The enzyme was preincubated with 1 mM EDTA in order to chelate any metal bound to the enzyme molecule prior to cation addition. ${ }^{b}$ Reference compound/condition set as $100 \%$ activity. ${ }^{c}$ All anions from sodium salts to avoid cation interference. ${ }^{\mathrm{d}}$ The specific activity for this compound was $196.5 \mathrm{U} / \mathrm{mg}$. ${ }^{\mathrm{e}}$ Apparent optimum temperature over $1 \mathrm{~h}$ reaction time.

chain lengths is typical of a true lipase and not an esterase [1]. In the Quick E test for enantioselectivity, LipC12 gave an $S / R$ rate ratio of $1.53 \pm 0.05$ with pure glycidyl butyrate enantiomers, indicating that LipC12 is not enantioselective for this compound under the conditions of the experiment. However, this does not eliminate the possibility that
LipC12 will show enantioselectivity for other compounds or under other reaction conditions.

Effect of detergents, gum arabic and modifying agents on LipC12 activity

Detergents such as Triton X-100 are usually added to lipase substrate emulsions to improve the emulsion 
quality, making the substrate more accessible. However, depending on the concentration used, detergents can also cause lipases to denature. For LipC12, at $0.1 \%(\mathrm{v} / \mathrm{v})$ concentration, the detergents CTAB, NLS and Triton X100 enhanced the activity up to $175 \%$ (Table 1). NP40 had no effect and SDS inhibited the activity by about $50 \%$. Although Tween 20, 40 and 60 are non-ionic detergents, as are Triton X-100 and NP40, they inhibited the activity as much or more than SDS. This effect is probably due to the long acyl ester chains of these detergents making them substrates for LipC12 and therefore competitive inhibitors in the assay. Interestingly, Tween 80 was the most effective inhibitor of $p$ NPP hydrolysis, suggesting that LipC12 has a preference for esters of C18 fatty acids over C16 (Tween 40) and $\mathrm{C} 12$ (Tween 20). At $1 \%(\mathrm{v} / \mathrm{v})$, all detergents decreased the activity significantly, with LipC12 tolerating best NP40 and Triton X-100. Since gum arabic is often added to stabilize lipase substrate emulsions [44], it is important to know its effect on LipC12 activity. At $0.5 \%(\mathrm{w} / \mathrm{v})$ the relative activity almost doubled. Modifying agents such as PMSF (specific inhibitor of serine hydrolases) and DEPC (histidine residue modifier) at 1 $\mathrm{mM}$ concentrations strongly reduced LipC12 activity (Table 1). This effect suggests that LipC12 does indeed have a catalytic triad containing serine and histidine residues [3].

\section{Residual activity of LipC12 after incubation in organic solvents}

The activities of LipC12 after $48 \mathrm{~h}$ incubation at $4^{\circ} \mathrm{C}$ in $15 \%$ and $30 \%(\mathrm{v} / \mathrm{v})$ of organic solvents was inhibited only in the cases of $15 \%(\mathrm{v} / \mathrm{v})$ acetone and $15 \%(\mathrm{v} / \mathrm{v})$ acetonitrile (Table 2). In all other cases the LipC12 activity after incubation was stimulated. This phenomenon is in fact quite well known. For example, Candida rugosa lipase is activated by organic solvents, which keep the lid of the enzyme in the open conformation, facilitating the access of the substrate to the active site $[45,46]$. Although the three-dimensional structure of LipC12 has not yet been determined, the increased LipC12 activity in this experiment suggests the existence of a lid that is converted from closed to open conformation in the presence of organic solvents. These findings are particularly significant, due to the fact that organic solvents have been used in biodiesel production through biocatalysis.

\section{Effect of $\mathrm{NaCl}$ and $\mathrm{KCl}$ concentrations on LipC12 activity and stability}

Addition of $\mathrm{NaCl}$ to a $p \mathrm{NPP}$ emulsion until $1.5 \mathrm{M}$ increased LipC12 activity up to 15 fold (Table 1), however, the activity decreased with further increases in the $\mathrm{NaCl}$ concentration. Since LipC12 is stable at $\mathrm{NaCl}$ concentrations up to $3.7 \mathrm{M}$ (Table 2) the decrease in activity above $1.5 \mathrm{M}$ is probably due to decreased substrate

Table 2 Effect of organic solvents, $\mathrm{pH}, \mathrm{NaCl}$ and temperature on the stability of LipC12

\begin{tabular}{|c|c|c|c|c|c|}
\hline Variable & $\begin{array}{l}\text { Residual } \\
\text { activity (\%) }\end{array}$ & Variable & $\begin{array}{l}\text { Residual } \\
\text { activity (\%) }\end{array}$ & Variable & $\begin{array}{l}\text { Residual } \\
\text { activity (\%) }\end{array}$ \\
\hline Solvent stability ${ }^{a}$ & & Solvent stability ${ }^{a}$ & & Sodium chloride $^{d}$ & \\
\hline None $^{\mathrm{b}}$ & $100.0 \pm 5.7$ & DMF $15 \%$ & $223.1 \pm 12.5$ & None $e^{b}$ & $100.0 \pm 6.5$ \\
\hline Methanol 15\% & $1204.1 \pm 20.6$ & DMF 30\% & $355.9 \pm 2.8$ & $0.9 \mathrm{M}$ & $100.9 \pm 8.5$ \\
\hline Methanol 30\% & $1561.1 \pm 72.4$ & Acetonitrile 15\% & $62.7 \pm 1.9$ & $1.9 \mathrm{M}$ & $102.2 \pm 7.1$ \\
\hline Ethanol 15\% & $587.6 \pm 28.2$ & Acetonitrile 30\% & $316.2 \pm 69.7$ & $2.3 \mathrm{M}$ & $99.7 \pm 5.0$ \\
\hline Ethanol 30\% & $428.4 \pm 39.1$ & pH stability ${ }^{c}$ & & $2.8 \mathrm{M}$ & $109.0 \pm 11.7$ \\
\hline 1-Propanol 15\% & $329.0 \pm 15.0$ & $A C 3$ & 0.0 & $3.2 \mathrm{M}$ & $99.1 \pm 7.7$ \\
\hline 1-Propanol 30\% & $1161.9 \pm 27.4$ & AC 4 & $83.9 \pm 5.3$ & $3.7 \mathrm{M}$ & $111.8 \pm 6.8$ \\
\hline 2-Propanol 15\% & $170.6 \pm 3.3$ & $A C 5$ & $85.7 \pm 5.9$ & Thermostability & \\
\hline 2-Propanol 30\% & $696.2 \pm 57.9$ & AC 5.5 & $70.5 \pm 4.0$ & $0^{\circ} \mathrm{C}^{\mathrm{b}}$ & $100.0 \pm 4.23$ \\
\hline Glycerol 15\% & $167.8 \pm 2.1$ & MES 5.5 & $77.9 \pm 6.1$ & $20.5^{\circ} \mathrm{C}$ & $100.0 \pm 1.0$ \\
\hline Glycerol 30\% & $233.0 \pm 6.4$ & MES 6 & $92.4 \pm 5.3$ & $30.0^{\circ} \mathrm{C}$ & $96.2 \pm 7.7$ \\
\hline THF 15\% & $463.6 \pm 139.4$ & MES 7 & $95.5 \pm 1.0$ & $40.0^{\circ} \mathrm{C}$ & $100.0 \pm 4.2$ \\
\hline THF 30\% & $1690.9 \pm 29.0$ & HEPES 7 & $95.7 \pm 8.1$ & $50.7^{\circ} \mathrm{C}$ & $94.0 \pm 6.4$ \\
\hline Acetone 15\% & $66.5 \pm 1.6$ & HEPES $7.5^{\mathrm{b}}$ & $100.0 \pm 4.9$ & $60.6^{\circ} \mathrm{C}$ & $75.8 \pm 4.0$ \\
\hline Acetone 30\% & $624.2 \pm 3.5$ & GLC 7.5 & $96.9 \pm 5.1$ & $70.0^{\circ} \mathrm{C}$ & $64.9 \pm 8.3$ \\
\hline Dioxane 15\% & $505.4 \pm 22.8$ & GLC 8 & $94.8 \pm 3.1$ & $81.0^{\circ} \mathrm{C}$ & $31.4 \pm 0.7$ \\
\hline Dioxane 30\% & $509.7 \pm 47.3$ & GLC 9 & $98.4 \pm 10.6$ & $90.2^{\circ} \mathrm{C}$ & $6.4 \pm 1.3$ \\
\hline DMSO 15\% & $263.7 \pm 10.1$ & GLC 10 & $99.0 \pm 5.3$ & & \\
\hline DMSO 30\% & $770.1 \pm 41.7$ & GLC 11 & $91.5 \pm 6.3$ & & \\
\hline
\end{tabular}

All measurements were performed using the pNPP method. Standard errors of the mean values are shown. ${ }^{\mathrm{a}}$ The enzyme was incubated for $48 \mathrm{~h}$ at $4^{\circ} \mathrm{C}$ in this assay. ${ }^{\mathrm{b}}$ Reference compound/condition set as $100 \%$ activity. ${ }^{c}$ LipC12 was incubated for $24 \mathrm{~h}$ at $4^{\circ} \mathrm{C}$ in each pH buffer. ${ }^{d}$ The enzyme was incubated for $24 \mathrm{~h}$ at $4^{\circ} \mathrm{C}$ in this assay. ${ }^{e}$ The enzyme was incubated for $1 \mathrm{~h}$ at each temperature. 
solubility, which was indicated by the emulsion becoming turbid at $3 \mathrm{M} \mathrm{NaCl}$. The same results about LipC12 stability were observed for $\mathrm{KCl}$ (results not shown). Enzyme stability at high salt concentrations might indicate that the enzyme will be stable in the low water activity environments that occur in biocatalytic reactions carried out in organic solvents [47].

\section{Effect of $\mathrm{pH}$ on LipC12 stability}

Determination of the $\mathrm{pH}$ stability of enzymes is important for identifying nondenaturing $\mathrm{pH}$ values of buffers for purification, storage and reaction steps. LipC12 showed a broad $\mathrm{pH}$ tolerance, with over $90 \%$ residual activity after $24 \mathrm{~h}$ incubation at $\mathrm{pH}$ values ranging from 6.0 to 11.0 (Table 2). At pH 3 LipC12 lost all activity and in the range of 4.0 to 5.5 the residual activity was between 70 and 90\%. The enzyme showed a local stability minimum at $\mathrm{pH} 5.5$, probably caused by isoelectric precipitation [48].

\section{Effect of temperature on LipC12 activity and stability}

In an enzymatic process there is a critical play between thermostability and the effect of temperature on activity. It is necessary to identify a reaction temperature that at the same time allows a reasonably high rate of reaction and keeps the rate of denaturation at a reasonably low level. LipC12 showed maximum activity at $30^{\circ} \mathrm{C}$ (Table 1 ) when incubated for $1 \mathrm{~h}$ and enzyme stability (during $1 \mathrm{~h}$ incubation) was not affected up to $50^{\circ} \mathrm{C}$ (Table 2). After $1 \mathrm{~h}$ at $70^{\circ} \mathrm{C}$ the enzyme retained about $65 \%$ of its original activity.

\section{Titrimetric determinations of lipase activity using} triacylglycerol substrates

LipC12 substrate specificity against triacylglycerols

As shown in Figure 4a, LipC12 was most active against tributyrin $(2187 \mathrm{U} / \mathrm{mg})$, pig fat $(1767 \mathrm{U} / \mathrm{mg})$ and olive oil (1722 U/mg), with relatively low activities against tripropionin $(344 \mathrm{U} / \mathrm{mg})$, castor oil $(215 \mathrm{U} / \mathrm{mg})$ and triacetin $(28 \mathrm{U} / \mathrm{mg})$. On the other hand, zymogram analysis (Figure 1d) and plate screening tests (results not shown) showed larger hydrolysis halos against trioctanoin than against tributyrin. In addition, when using $p$ NP substrates, LipC12 showed a preference for the C16 rather than the $\mathrm{C} 4$ acyl group. These results can be explained by the fact that the activity not only depends on the length of the acyl chain, but is also affected by factors such as the presence or absence of insaturations or hydroxyl groups in the acyl chain, the solubility of the triacylglycerol and the quality of the emulsion. LipC12 showed a relatively low activity against castor oil, probably because of the unusual hydroxyl functional group on the twelfth carbon of the ricinoleic acid.

\section{Effect of pH on LipC12 activity}

The effect of $\mathrm{pH}$ on activity was studied using tributyrin, in order to reduce buffering effects in the titrations: tributyrin has the smallest correction factor, due to its lower $\mathrm{pK}_{\mathrm{a}}$, compared with tricaprylin and triolein. Over a $\mathrm{pH}$ range of 4 to 10 , LipC12 displayed more than $90 \%$ relative activity at $\mathrm{pH}$ values above 7 ; the maximum activity was at $\mathrm{pH} 10$ and no activity was observed below pH 4.5 (Figure 4b). Thus this lipase is more active under neutral and alkaline conditions. Measurements at pH 11 and above were unreliable due to nonenzymatic tributyrin hydrolysis.

\section{Discussion}

The combination of fat contaminated soil and the prokaryotic DNA extraction protocol used were probably responsible for the high hit rate $(0.53 \%)$ of lipolytic active clones obtained. So far only two other works have reported a hit rate of this magnitude. Recently, Liaw et
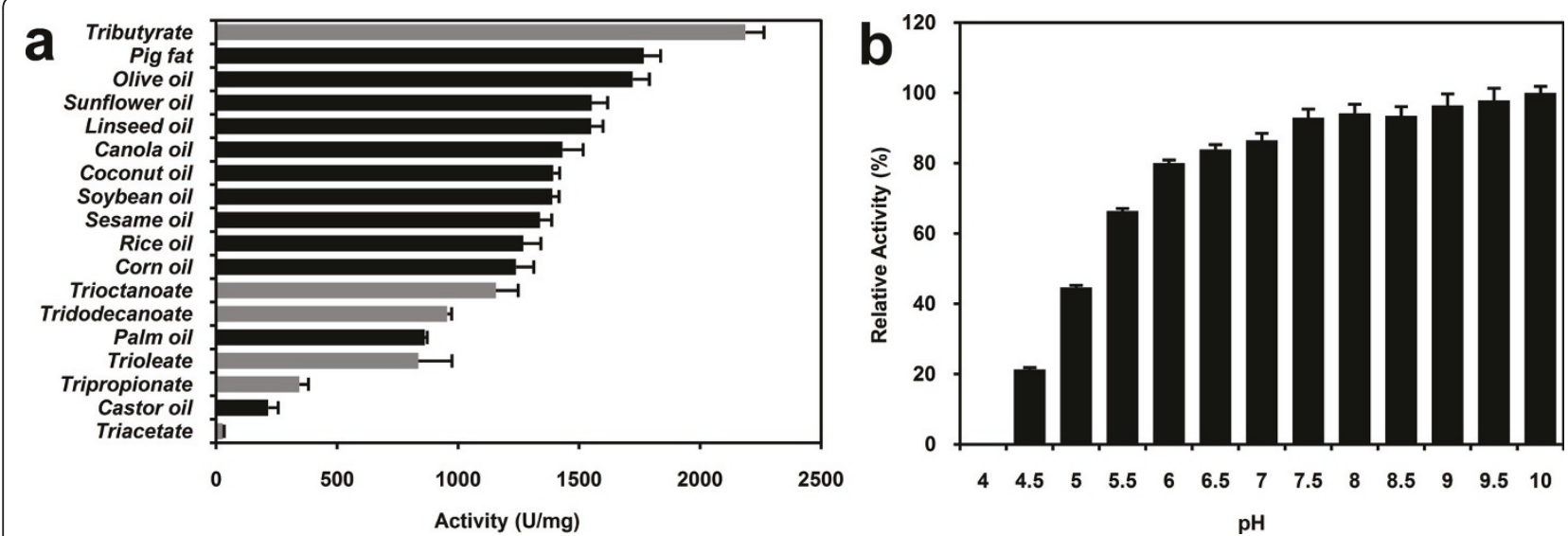

Figure 4 Enzymatic activity measurements obtained using the titrimetric method with triacylglycerols. (a) LipC12 substrate specificity against triacylglycerols. Among long-chain triglycerides, LipC12 showed the highest activities for pig fat and olive oil. (b) Effect of pH on LipC12 activity. LipC12 showed activity above $\mathrm{pH} 4.5$ and it is more active under neutral to alkaline conditions. 
al. (2010) obtained a hit rate of $0.31 \%$ (12 positives) for lipolytic clones with a metagenomic library constructed from an activated sludge of a swine wastewater treatment facility. They attributed their high hit rate to the sample source, which caused a natural enrichment in lipolytic organisms. A comparable effect seems to have occurred with the high-fat soil used in this study. Using the prokaryotic DNA extraction protocol, Hårdeman and Sjöling (2007) obtained a hit rate for lipolytic clones of $1 \%$ from a metagenomic library of Baltic Sea sediment with more than 7000 fosmids. When the prokaryotic DNA extraction technique or the enrichment step prior to DNA extraction are not applied, the hit rate of lipolytic clones in metagenomic libraries is typically lower, ranging from 0.001 to $0.081 \%$ [28].

The prokaryotic DNA extraction procedure circumvents two main problems. First, it is very difficult to extract DNA of high molecular weight for fosmid cloning from a soil with high organic matter content by direct lysis procedures [49]. Second, even though eukaryotic cells correspond to only $0.1 \%$ of the total number of cells in environmental samples, they may contribute about $90 \%$ of the total DNA due to their larger genome size. This eukaryotic DNA is unlikely to be expressed properly in E. coli but increases the library size [50].

In addition to the hit rate, the library size is a critical factor for success in a metagenome project. Metagenomics libraries used have diverse sizes, in most cases varying from few thousands to one million clones [51-53]. In the current work, both the elevated hit rate and the large size of the metagenomic library (approximately 500,000 clones) allowed the detection of 2,661 lipolytic clones, the largest number of lipolytic clones so far reported in a metagenomic study. Moreover, the three-stage screening strategy was able to discriminate triolein-active clones among the tricaprylin- and tributyrin-active clones, enabling the selection of a true lipase as well as the acquisition of lipolytic clone sublibraries for further screenings against oils and fats of interest.

Few lipases with high activity against long-chain triglycerides such as vegetable oils or animal fat have been found so far through the metagenomic approach. To the best of our knowledge, among metagenome-derived lipases, LipC12 has the highest specific activities against long-chain triglycerides (1767 and $1722 \mathrm{U} / \mathrm{mg}$ for pig fat and olive oil, respectively). In other metagenomic studies, EML1, a new cold-active lipase from a sediment metagenome, had a preference for medium-chain triglycerides, with a specific activity against trilaurin (C12) of $203 \mathrm{U} / \mathrm{mg}$ [35]; the lipases RlipE1 and RlipE2, isolated from a metagenomic library of cow rumen, had specific activities of 346 and $232 \mathrm{U} / \mathrm{mg}$, respectively, against triolein (C18) [36]; and LipG, from a metagenomic library of tidal flat sediments, had a specific activity against $p \mathrm{NPP}$ of $459 \mathrm{U} / \mathrm{mg}$, while for triglycerides only relative activities were presented, with the highest activity against triolein, followed by tricaprylin and tributyrin [33]. Other metagenome-derived lipases showed hydrolysis halos in triolein or olive oil plate assays but the specific activities against these substrates were not measured $[32,34,37]$.

In fact, the specific activity of LipC12 is comparable to that of the lipases of Rhizopus oryzae, Rhizomucor miehei and Thermomyces lanuginosus (formerly Humicola lanuginosa), which showed activities against olive oil of 1000, 3300 and $2900 \mathrm{U} / \mathrm{mg}$, respectively [54]. These are industrially used lipases with well-known high activity against long-chain triglycerides $[4,12,55]$.

\section{Conclusions}

We obtained a high hit rate of lipolytic activity in our metagenomic study by combining three strategies, namely the use of fat-contaminated soil, the use of a prokaryotic DNA enrichment step and the use of a three-step screening strategy in which the last step tested for true lipase activity. The lipase that we isolated, LipC12, is a novel lipase. Although it was initially selected solely on the basis of its high activity against triolein, it has characteristics that make it suitable for biotechnological applications such as activity and stability over a wide range of $\mathrm{pH}$ values, high activity and high thermal stability at ambient temperatures and stability in water-miscible organic solvents and at high salt concentrations. Moreover, production of recombinant LipC12 is convenient due its high solubility, easy purification through affinity chromatography and chaperonefree folding. LipC12 is a promising candidate for improvement of stability and activity by protein engineering, once the LipC12 three-dimensional structure is determined, or by directed evolution.

\section{Methods}

\section{Bacterial strains and plasmids}

Escherichia coli EPI300 ${ }^{\mathrm{TM}}-\mathrm{T} 1^{\mathrm{R}}$ and $\mathrm{pCC} 2 \mathrm{FOS}$ fosmid vector (CopyControl Fosmid Library Production Kit, Epicentre Biotechnologies, Madison, WI, USA) were used for constructing the metagenomic library. E. coli DH10B and the vectors pUC18 and pCR2.1 (Invitrogen Life Technologies, USA) were used for subcloning steps. E. coli BL21(DE3) and pET-28a(+) vector (Novagen, Madison, WI, USA) were used as the recombinant protein expression system.

\section{Chemicals and enzymes}

FideliTaq PCR Master Mix (USB, Cleveland, OH, USA) was used for DNA amplification. T4 DNA ligase, T4 DNA polymerase, Klenow fragment, T4 polynucleotide kinase, shrimp alkaline phosphatase (SAP), restriction 
enzymes and the protein molecular mass marker were purchased from Fermentas (Glen Burnie, MD, USA). The HiTrap Chelating HP column was purchased from GE Healthcare (Uppsala, Sweden). The nitrophenyl ester series, triacetin, tripropionin, tributyrin, trioctanoin, tridodecanoin, triolein, castor oil, BES buffer, $(R)$-glycidyl butyrate, $(S)$-glycidyl butyrate, resorufin butyrate and $p$ nitrophenol were purchased from Sigma-Aldrich (St. Louis, MO, USA). The natural oils for lipase analysis were commercial products purchased from a supermarket. All other chemicals used for lipase analysis were of analytical grade.

\section{Sample collection and DNA extraction}

Soil samples were collected from the banks of an anaerobic lagoon (GPS position, 24.56'11.11"S, 50 $7^{\prime 2} 27.06$ "W) of the wastewater treatment plant of a meat packing and dairy industry located in the state of Paraná, Brazil. The average soil temperature was $30^{\circ} \mathrm{C}$ and soil samples up to $3 \mathrm{~cm}$ of soil depth were aseptically stored for $24 \mathrm{~h}$ at ambient temperature and subjected to DNA extraction by an indirect lysis method [56], in which prokaryotic cells were separated from the sediment by low-speed centrifugation before cell lysis.

\section{Metagenomic library construction and screening for lipolytic activity}

Purified DNA samples were size-separated on a $0.7 \%$ low melting point (LMP) agarose gel in TAE buffer at $20 \mathrm{~V} / \mathrm{cm}$. DNA bands from 20 to $40 \mathrm{~kb}$ were excised from the gel and extracted by the phenol method [57]. A metagenomic DNA library was constructed using the CopyControl Fosmid Library production kit, according to the manufacturer's protocol (Epicentre Biotechnologies, Madison, WI, USA). For activity screening, the transformed cells were plated onto modified Luria-Bertani (LB) agar plates $(5 \mathrm{~g} / \mathrm{L}$ peptone, $3 \mathrm{~g} / \mathrm{L}$ yeast extract, $13 \mathrm{~g} / \mathrm{L}$ bacteriological agar, $10 \mathrm{~g} / \mathrm{L}$ gum arabic) containing $1 \%(\mathrm{v} / \mathrm{v})$ emulsified tributyrin as substrate. Cells were grown at $37^{\circ} \mathrm{C}$ for four days and transformants with clear halos around individual colonies were chosen as possible lipase/esterase producing clones. The selected clones were transferred to 96-well microtiter plates with Terrific Broth and subjected to a second screening for lipolytic activity on the modified LB agar except that $1 \%(\mathrm{v} / \mathrm{v})$ tricaprylin was used instead of tributyrin. Tricaprylin positive clones were transferred to 96-well microtiter plates and stored. True lipase producing clones were identified amongst the tricaprylin active clones by screening on modified LB agar containing $1 \%(\mathrm{v} / \mathrm{v})$ triolein. Three clones that showed the strongest lipase activity (FosC12, FosE6 and FosH10) were further analyzed.

\section{Subcloning and identification of the lipase gene}

Sublibraries of the FosC12, FosE6 and FosH10 fosmids were constructed in pUC18 vector and subclones were screened for lipolytic activity on modified LB agar medium with $1 \%(\mathrm{v} / \mathrm{v})$ triolein. The inserts of active subclones were sequenced on an ABI 377 Automated Sequencer (Applied Biosystems, USA) from both ends using DYEnamic ET Dye Terminator Kit (GE Life Sciences, USA). Sequence assembly and editing were performed with the CodonCode Aligner software (CodonCode Corporation, Dedham, MA, USA). The open reading frames (ORFs) were identified with the ORF Finder tool [58] and the amino acid sequences were compared with the non-redundant sequence database deposited at the NCBI using BLAST [59]. Fosmids Fos $\mathrm{C} 12$, FosE 6 and FosH10 had the same lipase gene. Thus, further cloning steps were performed using the FosC12 fosmid and the lipase protein sequence is hereafter denominated LipC12 (lipC12 gene).

\section{Lipase sequence analysis and phylogenetic tree construction}

Prediction of transmembrane regions and signal peptide sequence were performed using the TMHMM 2.0 [60] and SignalP 3.0 servers [61], respectively. Protein solubility prediction was carried out with the system SOSUI [62]. The ProtParam tool was used to calculate the theoretical parameters of the protein [63]. Multiple sequence alignment was performed with the ClustalW algorithm [64] in combination with Geneious software (Biomatters Ltd, Auckland, New Zealand). Phylogenetic analysis was carried out with the neighbor-joining method using MEGA version 5. Bootstrapping (10,000 replicates) was used to estimate the confidence levels of phylogenetic reconstructions [65]. GeneDoc version 2.7 was used for displaying and highlighting the multiple sequence alignments.

\section{Cloning of lipC12 gene}

The forward primer LipC12.L (5'CAACGTCAAAGAGGTTATTC3') and the reverse primer LipC12.R (5'CGAGTGCTATCGTTCATTTA3') were used in a PCR reaction (FideliTaq PCR Master Mix, USB, USA) for the amplification of a 966 bp fragment. The amplified gene was first cloned into the pCR 2.1 vector (TA Cloning Kit, Invitrogen, USA) according to the manufacturer's recommendations and recombinant plasmids were transformed into E. coli DH10B competent cells by electroporation. White colonies were picked, plasmids were extracted [66] and their inserts were sequenced with M13 forward and reverse primers to confirm the absence of mutations in lipC12. Recombinant plasmid was then digested with NdeI (cut at lipC12 translation 
start codon) and BamHI. The insert was ligated into the pET28a $(+)$ vector, which had been previously digested with the same restriction enzymes and dephosphorylated by SAP, yielding plasmid pET28a-lipC12, the insert of which was end-sequenced with the T7 promoter and terminator primers. Plasmid pET28a-lipC12 was then transformed into E. coli BL21(DE3) cells to express the recombinant (His)6-tagged LipC12 lipase.

\section{Overexpression and purification of recombinant LipC12 lipase}

E. coli BL21(DE3) cells carrying the pET28a-lipC12 plasmid were grown in $200 \mathrm{~mL}$ of $\mathrm{LB}$ medium at $37^{\circ} \mathrm{C}$ until an OD600 of 0.5 and induced by the addition of isopropyl- $\beta$-D thiogalactopyranoside (IPTG) to a final concentration of $0.5 \mathrm{mM}$. The induced culture was incubated for a further $16 \mathrm{~h}$ at $20^{\circ} \mathrm{C}$ before harvesting of the cells by centrifugation $(10,000 \times \mathrm{g}$ for $5 \mathrm{~min})$ at $4^{\circ} \mathrm{C}$. The cell pellet was resuspended in $35 \mathrm{~mL}$ of lysis buffer $(50 \mathrm{mM}$ Tris- $\mathrm{HCl} \mathrm{pH}$ 8.0, $500 \mathrm{mM} \mathrm{NaCl}, 10 \mathrm{mM}$ imidazole, 10 $\mathrm{mM} \beta$-mercaptoethanol, $10 \%$ (v/v) glycerol, $0.25 \%(\mathrm{w} / \mathrm{v})$ Nonidet P-40) and disrupted by ultrasonication in an ice bath (10 cycles of $60 \mathrm{~s}$ pulses, $90 \mathrm{~W}$, with $30 \mathrm{~s}$ intervals), using a SONICATOR ${ }^{\circledR}$ XL 2020 (Heat systems-Ultrasonics Inc., New Highway, Farmingdale, NY, USA). The crude extract was then centrifuged at $15,000 \times \mathrm{g}$ for 30 min at $4^{\circ} \mathrm{C}$ to pellet the cell debris. The supernatant containing the His-tagged protein was loaded onto a HiTrap Chelating HP column (GE Healthcare, USA), previously loaded with $\mathrm{Ni}^{2+}$ and equilibrated with lysis buffer, using an ÄKTAbasic chromatography system (GE Healthcare, USA). The column was washed with 5 volumes of the lysis buffer and further with 5 volumes of elution buffer (50 mM Tris- $\mathrm{HCl} \mathrm{pH} 8.0,500 \mathrm{mM}$ $\mathrm{NaCl}, 10 \mathrm{mM}$ imidazole, $10 \%$ (v/v) glycerol). The Histagged protein was eluted with an increasing gradient of imidazole up to $500 \mathrm{mM}$ in elution buffer. The elution of protein was monitored at $280 \mathrm{~nm}$, protein fractions were analyzed by SDS-PAGE, pooled, dialyzed $(50 \mathrm{mM}$ Tris- $\mathrm{HCl} \mathrm{pH} 8.0,150 \mathrm{mM} \mathrm{NaCl}, 10 \mathrm{mM} \mathrm{CaCl}_{2}, 50 \%$ (v/ v) glycerol) and stored at $-24^{\circ} \mathrm{C}$ until use.

\section{Protein content determination, electrophoresis and zymogram analyses}

Protein content was determined using the Pierce BCA Protein Assay Kit (Pierce Biotechnology, Rockford, IL, USA) with bovine serum albumin as the standard. Electrophoresis of protein samples was done with $12 \%(\mathrm{w} / \mathrm{v})$ SDS-PAGE [67] and the gel was stained with Coomassie Brilliant Blue R-250 and destained with methanol/ acetic-acid/water (5/1/4 v/v/v). Densitometric analysis of the stained SDS-PAGE gel was done using LabWorks Image Acquisition and Analysis Software 4.0 (UVP BioImaging Systems, Upland, CA, USA). Lipolytic activity of bands on the SDS-PAGE gel was detected using tributyrin or tricaprylin as substrate [68].

\section{MALDI-TOF/MS analysis}

Matrix-assisted laser desorption/ionization (MALDI) time-of-flight (TOF) mass spectra (MS) were acquired on a MALDI-TOF/TOF Autoflex II spectrometer (Bruker Daltonics, Bremen, Germany) in the reflector positive ion mode with an acceleration voltage of $20 \mathrm{kV}$, delay time of $150 \mathrm{~ns}$ and acquisition mass range 8003200 Da. Spots were excised manually and in-gel digested with sequencing grade modified trypsin (Promega, Madison, USA) as described elsewhere [69]. The sample was desalted using a ZipTipC 18 pipette tip (Millipore Corporation, Bedford, MA, USA) and eluted directly onto the MALDI target plate using MALDI matrix (saturated solution of $\alpha$-cyano-4-hydroxycinnamic acid in $50 \%(\mathrm{v} / \mathrm{v})$ acetonitrile and $0.1 \%$ TFA). Mass profiles were identified by comparing the peptide masses obtained with in silico digestion of the Histagged protein sequence using PeptideCutter and MSDigest tools [63].

\section{Spectrophotometric determinations of lipase activity using pNP substrates}

Enzymatic activities were determined by following the amount of $p$-nitrophenol released from $p$-nitrophenyl ester at $410 \mathrm{~nm}$ [70] for at least $30 \mathrm{~min}$ at $30^{\circ} \mathrm{C}$ in a TECAN Infinite Series M200 microplate spectrophotometer (TECAN, Salzburg, Austria). Unless otherwise described, for the standard assay, the substrate solution was made by mixing a stock solution of $20 \mathrm{mM}$ of $p$ nitrophenyl palmitate ( $p$ NPP) in acetonitrile/isopropanol $(1 / 4 \mathrm{v} / \mathrm{v})$ with an assay buffer containing Tris- $\mathrm{HCl}$ $\mathrm{pH} 7.5, \mathrm{CaCl}_{2}$ and Triton $\mathrm{X}-100$, under agitation in a water bath at $60^{\circ} \mathrm{C}$, until the solution became transparent. Then $230 \mu \mathrm{L}$ of the substrate solution was pipetted into a 96-well microtiter plate and the reaction was initiated by automatic addition (with the TECAN injector module) of $20 \mu \mathrm{L}$ of the enzyme solution $\left(50 \mathrm{mM}\right.$ Tris- $\mathrm{HCl} \mathrm{pH} \mathrm{7.5,1} \mathrm{mM} \mathrm{CaCl}_{2}$ ) to a final concentration of $5 \mathrm{nM}$. The final volume of the reaction mixture (Tris- $\mathrm{HCl} 50 \mathrm{mM}, \mathrm{pH} 7.5,1 \mathrm{mM} \mathrm{CaCl}_{2}$, $0.3 \%(\mathrm{v} / \mathrm{v})$ Triton $\mathrm{X}-100,5 \mathrm{nM}$ enzyme, $1 \mathrm{mM} p \mathrm{NPP}$, $4 \%(\mathrm{v} / \mathrm{v})$ isopropanol, $1 \%(\mathrm{v} / \mathrm{v})$ acetonitrile) was 250 $\mu \mathrm{L}$. All experiments were performed in triplicate, the extinction coefficients of $p$-nitrophenol were determined under each reaction condition and the effect of nonenzymatic hydrolysis of substrates was subtracted. One unit of lipase activity was defined as $1 \mu \mathrm{mol}$ of $p$ nitrophenol produced per minute. Linear regressions to determine initial reaction velocities and standard deviations of means were performed with Calc software from the OpenOffice.org package. 
Substrate specificity for nitrophenyl esters was analyzed under standard conditions using $p$-nitrophenyl acetate $(\mathrm{C} 2: 0), p$-nitrophenyl butyrate $(\mathrm{C} 4: 0), p$-nitrophenyl valerate (C5:0), $p$-nitrophenyl caproate (C6:0), $p$ nitrophenyl decanoate (C10:0), $p$-nitrophenyl dodecanoate $(\mathrm{C} 12: 0), p$-nitrophenyl myristate $(\mathrm{C} 14: 0)$ and $p$-nitrophenyl palmitate (C16:0).

The temperature giving maximum substrate conversion over a $1 \mathrm{~h}$ reaction time was determined by incubating the enzyme with $p$-nitrophenyl ester ( $2 \mathrm{nM}$ enzyme, 10 $\mathrm{mM}$ p-nitrophenyl butyrate, MES $50 \mathrm{mM}$ pH 6.0, $1 \mathrm{mM}$ $\mathrm{CaCl}_{2}, 0.3 \%$ (v/v) Triton X-100, 4\% (v/v) isopropanol, $1 \%$ $(\mathrm{v} / \mathrm{v})$ acetonitrile) in a reaction volume of $50 \mu \mathrm{L}$ at various temperatures within the range of $10^{\circ} \mathrm{C}$ to $60^{\circ} \mathrm{C}$. In relation to the standard assay, $p$-nitrophenyl butyrate was used instead of $p$ NPP to minimize substrate solubility variations with reaction temperature and the reaction $\mathrm{pH}$ was decreased to minimize substrate autohydrolysis, which occurs at higher temperatures. The reaction was carried out in a 96-well PCR plate on a Thermal Cycler (Eppendorf, Hamburg, Germany) running in gradient mode. After the reaction time, the plate was immediately chilled on ice and the enzymatic reaction was stopped by the addition of $100 \mu \mathrm{L}$ of $0.1 \mathrm{M} \mathrm{HCl}$. Then $125 \mu \mathrm{L}$ was transferred to a 96-well microtiter plate, completed to $250 \mu \mathrm{L}$ with deionized water and the amount of released $p$-nitrophenol was measured at $348 \mathrm{~nm}$ instead of 410 $\mathrm{nm}$ : the absorption of $p$-nitrophenol decreases at $410 \mathrm{~nm}$ as the $\mathrm{pH}$ decreases, due to changes in equilibrium between $p$-nitrophenol and $p$-nitrophenoxide, while 348 $\mathrm{nm}$ is the $\mathrm{pH}$-independent isosbestic wavelength of $p$ nitrophenoxide and $p$-nitrophenol [71].

The effect of cations and anions on the enzymatic activity of LipC12 was also investigated. For analyses involving cations, the enzyme at $250 \mathrm{nM}$ was previously incubated with $1 \mathrm{mM}$ EDTA/50 mM Tris- $\mathrm{HCl} \mathrm{pH} 7.5$ for $1 \mathrm{~h}$ in order to remove cations from the enzyme. Then $20 \mu \mathrm{L}$ of enzyme solution was added to each well of a 96-well microtiter plate, followed by $25 \mu \mathrm{L}$ of cation solution and $205 \mu \mathrm{L}$ of substrate solution (with $0.5 \mathrm{mM}$ of EDTA) giving a reaction mixture (Tris- $\mathrm{HCl} 50 \mathrm{mM}$ $\mathrm{pH} 7.5,1 \mathrm{mM}$ of a specific cation, $0.3 \%$ (v/v) Triton X100, $20 \mathrm{nM}$ enzyme, $1 \mathrm{mM} p \mathrm{NPP}, 0.5 \mathrm{mM}$ EDTA, 4\% $(\mathrm{v} / \mathrm{v})$ isopropanol, $1 \%(\mathrm{v} / \mathrm{v})$ acetonitrile) that was monitored at $410 \mathrm{~nm}$, as described above. The effect of cations on the enzymatic activity of LipC12 without previous cation depletion was also tested. For analyses involving anions, cation depletion with EDTA was not performed and a standard assay was carried out except that either $1 \mathrm{mM}$ or $10 \mathrm{mM}$ of a specific anion was added (all anions were added in the form of sodium salts).

Similarly, the effects of lipase inhibitors were investigated. Chelating agents such as ethylenediamine tetraacetic acid (EDTA) and ethylene glycol tetraacetic acid (EGTA) and modifying reagents such as phenylmethylsulfonyl fluoride (PMSF) and diethyl pyrocarbonate (DEPC) were used. The effects on LipC12 activity of commonly used detergents such as Tween 20, Tween 40, Tween 80, Triton X-100, Nonidet P-40 (NP40), sodium dodecyl sulfate (SDS), Sarkosyl NL (NLS) and hexadecyltrimethylammonium bromide (CTAB) were also investigated. The effect of gum arabic, commonly used as an emulsion stabilizer, was checked. In these cases, the activity measurements were done using the standard assay, except that the chemicals listed above were added to the wells before the addition of the substrate and enzyme solutions.

Thermostability was determined by measuring the residual activity after incubating $250 \mathrm{nM}$ of the enzyme (50 mM Tris- $\mathrm{HCl} \mathrm{pH} \mathrm{7.5,} 5 \mathrm{mM} \mathrm{CaCl}_{2}$ ) at various temperatures in the range of $0^{\circ} \mathrm{C}$ to $90^{\circ} \mathrm{C}$ for $1 \mathrm{~h}$ in $200 \mu \mathrm{L}$ PCR Eppendorf tubes with mineral oil on top to prevent evaporation. The incubation was carried out using a volume of $50 \mu \mathrm{L}$ on the Thermal Cycler (Eppendorf, Hamburg, Germany) running in gradient mode. After the incubation time, the tubes were chilled on ice and the residual activity was determined at $10 \mathrm{nM}$ of enzyme in the reaction mixture.

Stability in organic solvents was determined by measuring the residual activity after incubation of the enzyme at $500 \mathrm{nM}$ with $15 \%$ or $30 \%(\mathrm{v} / \mathrm{v})$ organic solvents $\left(200 \mathrm{mM}\right.$ Tris- $\left.\mathrm{HCl} \mathrm{pH} \mathrm{8.0,5} \mathrm{mM} \mathrm{CaCl}_{2}\right)$ at $4^{\circ} \mathrm{C}$ for $48 \mathrm{~h}$. In order to equalize the solvent concentration before the residual activity measurement, the solvent concentration of each solvent incubated at $15 \%(\mathrm{v} / \mathrm{v})$ was corrected to $0.3 \%(\mathrm{v} / \mathrm{v})$ during dilution of the enzyme (the enzyme was diluted 100-fold before performing the residual activity measurement).

Stability in high salt concentrations, up to $3.7 \mathrm{M}$, was investigated by incubating LipC12 at $785 \mathrm{nM}(1 \mathrm{mM}$ $\mathrm{CaCl}_{2}, 50 \mathrm{mM}$ Tris- $\mathrm{HCl} \mathrm{pH} \mathrm{7.5)} \mathrm{for} 24 \mathrm{~h}$ at $4^{\circ} \mathrm{C}$. Several $\mathrm{NaCl}$ and $\mathrm{KCl}$ concentrations were tested. All salt concentrations were equalized to $37 \mathrm{mM}$ during the 100fold dilution of the enzyme prior to the residual activity measurement.

The $\mathrm{pH}$ stability was tested after incubation of the purified enzyme for $24 \mathrm{~h}$ at $4^{\circ} \mathrm{C}$ in different buffers. For a $\mathrm{pH}$ range of 3.0 to 11.0 , the buffers used were $50 \mathrm{mM}$ sodium acetate ( $\mathrm{pH} 3.0$ to 5.5 ), $50 \mathrm{mM}$ MES (pH 5.5 to 7.0), $50 \mathrm{mM}$ HEPES ( $\mathrm{pH} 7.0$ to 7.5), and $50 \mathrm{mM}$ glycine ( $\mathrm{pH} 7.5$ to 11 ). The enzyme was diluted 100-fold in 50 mM HEPES pH 7.5 for the residual activity measurement under standard assay conditions.

Determination of lipase enantioselectivity was performed using the Quick E method [72-74]. Substrate solutions were prepared using glycidyl butyrate enantiomers and resorufin butyrate was used as the reference 
substrate. A buffer/indicator solution was prepared by mixing 4-nitrophenol solution $(1.2 \mathrm{~mL}$ of a $1.8 \mathrm{mM}$ solution in $1.0 \mathrm{mM}$ BES containing $0.33 \mathrm{mM}$ Triton X100, pH 7.2), BES buffer (3.3 mL of a $1.0 \mathrm{mM}$ solution containing $0.33 \mathrm{mM}$ Triton $\mathrm{X}-100, \mathrm{pH} 7.2)$, and acetonitrile $(65 \mu \mathrm{L})$. Substrate solution $(35 \mu \mathrm{L}$ of a $150 \mathrm{mM}$ glycidyl butyrate enantiomer in acetonitrile) and resorufin ester solution $(260 \mu \mathrm{L}$ of $2.0 \mathrm{mM}$ resorufin butyrate in acetonitrile) were added dropwise with continuous vortexing to form a clear emulsion that was stable for at least several hours. This solution was pipetted into a 96well polystyrene microplate $(100 \mu \mathrm{L} /$ well $)$. Lipase solution ( $5 \mu \mathrm{L}$ in $5 \mathrm{mM}$ BES) was added to each well and the microplate was placed in the microplate reader (TECAN Infinite Series M200 microplate spectrophotometer, TECAN, Salzburg, Austria) and shaken for $10 \mathrm{~s}$. Then the decrease in absorbance at $404 \mathrm{~nm}$ and the increase in absorbance at $574 \mathrm{~nm}$ were followed for 30 min at $25^{\circ} \mathrm{C}$. Blanks without enzyme were carried out for each substrate and data were collected in triplicate. Reaction rates for the reference substrate and each enantiomer were calculated using Eqs. (1) and (2), respectively, using the initial linear parts of the curves of absorbance versus time:

$$
\begin{aligned}
& \text { rate }_{\text {ref }}(\mu \mathrm{mol} / \mathrm{min})=\frac{\mathrm{d} A_{574} / \mathrm{d} t}{\Delta \varepsilon_{574} \times l} \times V \times 10^{6} \\
& \text { rate }_{\text {enan }}(\mu \mathrm{mol} / \mathrm{min})=-1.1\left(\text { rate }_{\mathrm{ref}}\right)+ \\
& {\left[\frac{\mathrm{d} A_{404} / \mathrm{d} t}{\Delta \varepsilon_{404} \times l} \times\left(\frac{[\text { buffer }]}{[\text { indicator }]}+1\right) \times V \times 10^{6}\right]}
\end{aligned}
$$

where $\mathrm{d} A_{574} / \mathrm{d} t$ is the absorbance increase (at $574 \mathrm{~nm}$ ) per minute, $\Delta \varepsilon_{574}$ is the difference in extinction coefficients at $574 \mathrm{~nm}$ for resorufin and resorufin butyrate $\left(15,100 \mathrm{M}^{-1} \mathrm{~cm}^{-1}\right), l$ is the path length $(0.3064 \mathrm{~cm}$ for a $105 \mu$ reaction volume), $V$ is the reaction volume in liters, $\mathrm{d} A_{404} / \mathrm{d} t$ is the absorbance decrease (at $404 \mathrm{~nm}$ ) per minute and $\Delta \varepsilon_{404}$ is the difference in extinction coefficients for the protonated and unprotonated forms of the 4-nitrophenol $\left(17,300 \mathrm{M}^{-1} \mathrm{~cm}^{-1}\right)$.

The enantioselectivity was calculated from two measurements (one for each glycidyl butyrate enantiomer) as shown in Eq. (3):

$$
\text { Quick E }(S / R)=\frac{\text { rate }_{S}}{\text { rate }_{\mathrm{refS}}} \times \frac{\text { rate }_{\mathrm{refR}}}{\text { rate }_{\mathrm{R}}}
$$

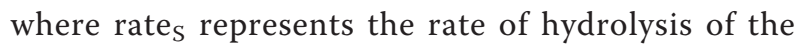
$(S)$-glycidyl butyrate enantiomer and rate ${ }_{\text {refs }}$ is the rate of hydrolysis of the reference substrate (resorufin butyrate) in the presence of the $(S)$-enantiomer. Analogous definitions apply for rate $_{R}$ and rate $_{\text {refR }}$ in terms of the $(R)$-enantiomer.
Titrimetric determinations of lipase activity using triacylglycerol substrates

The substrate emulsions consisted of triacylglycerol 67 $\mathrm{mM}$, gum arabic 3\% (w/v), $\mathrm{CaCl}_{2} 2 \mathrm{mM}$, Tris- $\mathrm{HCl} 2.5$ $\mathrm{mM}$ and $\mathrm{NaCl} 150 \mathrm{mM}$, dispersed in distilled water [75]. The solution was emulsified with a handheld mixer (400 watts, Royal Philips Electronics) at high speed, initially for $10 \mathrm{~min}$ and then for an additional $2 \mathrm{~min}$ immediately before use. The free fatty acids released during the reaction were titrated automatically in a Metrohm 718 STAT Titrino potentiometric titrator (Metrohm, Herisau, Switzerland) with $0.05 \mathrm{M} \mathrm{NaOH}$, for $5 \mathrm{~min}$. The reactions were done in a glass vessel thermostated at $30^{\circ} \mathrm{C}$ containing $20 \mathrm{~mL}$ of substrate emulsion and $6.68 \mu \mathrm{g}$ of purified enzyme added in 200 $\mu \mathrm{L}$ of solution buffer (Tris- $\mathrm{HCl} 2.5 \mathrm{mM} \mathrm{pH} \mathrm{8,} \mathrm{CaCl}_{2} 5$ $\mathrm{mM})$. The titration point was set to $\mathrm{pH} 8.5$. All measurements were performed in triplicate and chemical hydrolysis of the substrate was subtracted. One unit (U) of enzymatic activity was defined as the release of 1 $\mu \mathrm{mol}$ of fatty acid per minute.

The $\mathrm{pH}$ optimum for LipC12 was determined using tributyrin as a substrate [40]. The substrate emulsion and reaction conditions were the same as described above except that the setpoint $\mathrm{pH}$ was set at different values. Corrections were made for autohydrolysis and for the partial dissociation of butanoic acid assuming a $\mathrm{pK}_{\mathrm{a}}$ of 4.57 .

\section{Nucleotide sequence accession number}

The LipC12 nucleotide sequence reported here is available in the GenBank database under the accession number JF417979.

\section{Acknowledgements}

This work was supported by INCT-FBN/CNPq/MCT, CAPES, Institutos do Milênio/CNPq/MCT and PRONEX/Fundação Araucária. We thank the Brazilian National Council for Scientific and Technological Development (CNPq) and the Coordination for the Development of Higher Education Personnel (CAPES) for research scholarships. We thank Roseli Prado, Julieta Pie, Marilza Doroti Lamour and Valter A. de Baura for technical support.

\section{Author details}

${ }^{1}$ Department of Biochemistry and Molecular Biology, Federal University of Paraná, Curitiba/PR, Brazil. ${ }^{2}$ Department of Chemistry, Federal University of Paraná, Curitiba/PR, Brazil.

\section{Authors' contributions}

NK, FOP and EMS conceived, supervised and coordinated this study. AG participated in the experimental design, carried out the cloning steps, protein purification, enzyme analyses and interpretation of data and wrote the manuscript. HF and MM-S contributed to metagenomic library construction. GHC and RAM participated in subcloning and sequencing steps. VPM participated in protein expression and purification, and contributed to interpretation of enzyme activity analyses. NK and DAM contributed to the analysis and interpretation of data and to the writing of the manuscript. EMS and MM-S critically revised the manuscript. All authors read and approved the final manuscript. 


\section{Competing interests}

The authors declare that they have no competing interests.

Received: 30 May 2011 Accepted: 15 July 2011 Published: 15 July 2011

\section{References}

1. Jaeger KE, Dijkstra BW, Reetz MT: Bacterial biocatalysts: molecular biology, three-dimensional structures, and biotechnological applications of lipases. Annu Rev Microbiol 1999, 53:315-351.

2. Jaeger KE, Eggert T: Lipases for biotechnology. Curr Opin Biotechnol 2002, 13:390-397.

3. Gupta R, Gupta N, Rathi P: Bacterial lipases: an overview of production, purification and biochemical properties. Appl Microbiol Biotechnol 2004, 64:763-781.

4. Hasan F, Shah AA, Hameed A: Industrial applications of microbial lipases. Enzyme Microb Technol 2006, 39:235-251.

5. Shu Z-Y, Jiang H, Lin R-F, Jiang Y-M, Lin L, Huang J-Z: Technical methods to improve yield, activity and stability in the development of microbial lipases. J Mol Catal B: Enzym 2010, 62:1-8.

6. Xiao M, Mathew S, Obbard JP: Biodiesel fuel production via transesterification of oils using lipase biocatalyst. GCB Bioenergy 2009, 1:115-125

7. Bajaj A, Lohan P, Jha PN, Mehrotra R: Biodiesel production through lipase catalyzed transesterification: an overview. J Mol Catal B: Enzym 2010, 62:9-14

8. Bisen PS, Sanodiya BS, Thakur GS, Baghel RK, Prasad G: Biodiesel production with special emphasis on lipase-catalyzed transesterification. Biotechnol Lett 2010, 32:1019-1030.

9. Xu XB: Production of specific-structured triacylglycerols by lipasecatalyzed reactions: a review. Eur J Lipid Sci Technol 2000, 102:287-303.

10. Hayes DG: Enzyme-catalyzed modification of oilseed materials to produce eco-friendly products. J Am Oil Chem Soc 2004, 81:1077-1103.

11. Hasan F, Shah AA, Javed S, Hameed A: Enzymes used in detergents: lipases. Afr J Biotechnol 2010, 9:4836-4844.

12. Houde A, Kademi A, Leblanc D: Lipases and their industrial applications an overview. Appl Biochem Biotechnol 2004, 118:155-170.

13. Jaeger KE, Eggert T, Eipper A, Reetz MT: Directed evolution and the creation of enantioselective biocatalysts. Appl Microbiol Biotechnol 2001, 55:519-530.

14. Liu DN, Trodler P, Eiben S, Koschorreck K, Muller M, Pleiss J, Maurer SC, Branneby C, Schmid RD, Hauer B: Rational design of Pseudozyma antarctica lipase $B$ yielding a general esterification catalyst. ChemBioChem 2010, 11:789-795.

15. Syren PO, Lindgren E, Hoeffken HW, Branneby C, Maurer S, Hauer B, Hult K: Increased activity of enzymatic transacylation of acrylates through rational design of lipases. J Mol Catal B: Enzym 2010, 65:3-10.

16. Steele HL, Jaeger KE, Daniel R, Streit WR: Advances in recovery of novel biocatalysts from metagenomes. J Mol Microbiol Biotechnol 2009, 16:25-37.

17. Lämmle K, Zipper H, Breuer M, Hauer B, Buta C, Brunner H, Rupp S: Identification of novel enzymes with different hydrolytic activities by metagenome expression cloning. J Biotechnol 2007, 127:575-592.

18. Rondon MR, August PR, Bettermann AD, Brady SF, Grossman TH, Liles MR, Loiacono KA, Lynch BA, MacNeil IA, Minor C, Tiong CL, Gilman M, Osburne MS, Clardy J, Handelsman J, Goodman RM: Cloning the soil metagenome: a strategy for accessing the genetic and functional diversity of uncultured microorganisms. Appl Environ Microbiol 2000, 66:2541-2547.

19. Henne A, Schmitz RA, Bomeke M, Gottschalk G, Daniel R: Screening of environmental DNA libraries for the presence of genes conferring lipolytic activity on Escherichia coli. Appl Environ Microbiol 2000, 66:3113-3116.

20. Yun J, Ryu S: Screening for novel enzymes from metagenome and SIGEX, as a way to improve it. Microb Cell Fact 2005, 4:8.

21. Lorenz P, Eck J: Metagenomics and industrial applications. Nat Rev Microbiol 2005, 3:510-516

22. Kakirde KS, Parsley LC, Liles MR: Size does matter: application-driven approaches for soil metagenomics. Soil Biol Biochem 2010, 42:1911-1923.

23. Kennedy J, Marchesi JR, Dobson ADW: Marine metagenomics: strategies for the discovery of novel enzymes with biotechnological applications from marine environments. Microb Cell Fact 2008, 7:27.
24. Jiang C, Wu L-L, Zhao G-C, Shen P-H, Jin K, Hao Z-Y, Li S-X, Ma G-F, Luo F-F, Hu G-Q, Kang W-L, Qin X-M, Bi Y-L, Tang X-L, Wu B: Identification and characterization of a novel fumarase gene by metagenome expression cloning from marine microorganisms. Microb Cell Fact 2010, 9:91.

25. Handelsman J, Rondon MR, Brady SF, Clardy J, Goodman RM: Molecular biological access to the chemistry of unknown soil microbes: a new frontier for natural products. Chem Biol 1998, 5:R245-R249.

26. Simon C, Daniel R: Achievements and new knowledge unraveled by metagenomic approaches. Appl Microbiol Biotechnol 2009, 85:265-276.

27. Uchiyama T, Miyazaki K: Functional metagenomics for enzyme discovery: challenges to efficient screening. Curr Opin Biotechnol 2009, 20:616-622.

28. Liaw R-B, Cheng M-P, Wu M-C, Lee C-Y: Use of metagenomic approaches to isolate lipolytic genes from activated sludge. Bioresour Technol 2010, 101:8323-8329

29. Li G, Wang K, Liu Y: Molecular cloning and characterization of a nove pyrethroid-hydrolyzing esterase originating from the Metagenome. Microb Cell Fact 2008, 7:38.

30. Zhang T, Han WJ, Liu ZP: Gene cloning and characterization of a novel esterase from activated sludge metagenome. Microb Cell Fact 2009, 8:67.

31. Li JG, Zhang KG, Han WJ: Cloning and biochemical characterization of a novel lipolytic gene from activated sludge metagenome, and its gene product. Microb Cell Fact 2010, 9:83.

32. Jiang ZB, Wang HP, Ma YS, Wei DZ: Characterization of two novel lipase genes isolated directly from environmental sample. Appl Microbiol Biotechnol 2006, 70:327-332.

33. Lee MH, Lee $\mathrm{CH}$, Oh TK, Song JK, Yoon JH: Isolation and characterization of a novel lipase from a metagenomic library of tidal flat sediments: evidence for a new family of bacterial lipases. Appl Environ Microbiol 2006, 72:7406-7409.

34. Elend C, Schmeisser C, Hoebenreich H, Steele HL, Streit WR: Isolation and characterization of a metagenome-derived and cold-active lipase with high stereospecificity for (R)-ibuprofen esters. J Biotechnol 2007, 130:370-377.

35. Jeon JH, Kim JT, Kim YJ, Kim HK, Lee HS, Kang SG, Kim SJ, Lee JH: Cloning and characterization of a new cold-active lipase from a deep-sea sediment metagenome. Appl Microbiol Biotechnol 2009, 81:865-874.

36. Liu KL, Wang JQ, Bu DP, Zhao SG, McSweeney C, Yu P, Li D: Isolation and biochemical characterization of two lipases from a metagenomic library of China Holstein cow rumen. Biochem Biophys Res Commun 2009, 385:605-611.

37. Meilleur C, Hupé JF, Juteau P. Shareck F: Isolation and characterization of a new alkali-thermostable lipase cloned from a metagenomic library. $J$ Ind Microbiol Biotechnol 2009, 36:853-861.

38. Tirawongsaroj P, Sriprang R, Harnpicharnchai P, Thongaram T, Champreda V, Tanapongpipat S, Pootanakit K, Eurwilaichitr L: Novel thermophilic and thermostable lipolytic enzymes from a Thailand hot spring metagenomic library. J Biotechnol 2008, 133:42-49.

39. Arpigny JL, Jendrossek $D$, Jaeger KE: A novel heat-stable lipolytic enzyme from Sulfolobus acidocaldarius DSM 639 displaying similarity to polyhydroxyalkanoate depolymerases. Fems Microbiol Lett 1998, 167:69-73.

40. Elend C, Schmeisser C, Leggewie C, Babiak P, Carballeira JD, Steele HL, Reymond JL, Jaeger KE, Streit WR: Isolation and biochemical characterization of two novel metagenome-derived esterases. App/ Environ Microbiol 2006, 72:3637-3645.

41. Ollis DL, Shea E, Cygler M, Dijkstra B, Frolow F: The $\alpha / \beta$ hydrolase fold. Protein Eng 1992, 5:197.

42. Arpigny $J$ L, Jaeger KE: Bacterial lipolytic enzymes: classification and properties. Biochem J 1999, 343 Pt 1:177-183.

43. Nardini M, Lang DA, Liebeton K, Jaeger KE, Dijkstra BW: Crystal structure of Pseudomonas aeruginosa lipase in the open conformation. The prototype for family 1.1 of bacterial lipases. J Biol Chem 2000, 275:31219-31225

44. Hasan F, Shah AA, Hameed A: Methods for detection and characterization of lipases: a comprehensive review. Biotechnol Adv 2009, 27:782-798.

45. Grochulski P, Li Y, Schrag JD, Bouthillier F, Smith P: Insights into interfacial activation from an open structure of Candida rugosa lipase. $J$ Biol Chem 1993, 268:12843

46. Colton IJ, Ahmed SN, Kazlauskas RJ: A 2-propanol treatment increases the enantioselectivity of Candida rugosa lipase toward esters of chiral carboxylic-acids. J Org Chem 1995, 60:212-217. 
47. Eichler J: Biotechnological uses of archaeal extremozymes. Biotechnol Adv 2001, 19:261-278.

48. Scopes RK: Protein purification: priciples and practice New York: SpringerVerlag; 1994

49. Rajendhran J, Gunasekaran P: Strategies for accessing soil metagenome for desired applications. Biotechnol Adv 2008, 26:576-590.

50. Gabor EM, de Vries EJ, Janssen DB: Efficient recovery of environmental DNA for expression cloning by indirect extraction methods. Fems Microbiol Ecol 2003, 44:153-163.

51. Riesenfeld CS, Schloss PD, Handelsman J: Metagenomics: genomic analysis of microbial communities. Annu Rev Genet 2004, 38:525-552.

52. Daniel R: The metagenomics of soil. Nat Rev Microbiol 2005, 3:470-478.

53. Kimura N: Metagenomics: access to unculturable microbes in the environment. Microbes Environ 2006, 21:201-215.

54. Nini L, Sarda L, Comeau L-C, Boitard E, Dubès J-P, Chahinian H: Lipasecatalysed hydrolysis of short-chain substrates in solution and in emulsion: a kinetic study. Biochim Biophys Acta, Mol Cell Biol Lipids 2001, 1534:34-44.

55. Sharma R, Chisti Y, Banerjee UC: Production, purification, characterization, and applications of lipases. Biotechnol Adv 2001, 19:627-662.

56. Hårdeman F, Sjöling S: Metagenomic approach for the isolation of a novel low-temperature-active lipase from uncultured bacteria of marine sediment. Fems Microbiol Ecol 2007, 59:524-534.

57. Sambrook J, Maniatis T, Fritsch EF: Molecular cloning: a laboratory manual Cold Spring Harbor: Cold Spring Harbor Laboratory Press; 1989

58. Wheeler DL, Barrett T, Benson DA, Bryant SH, Canese K, Chetvernin V, Church DM, Dicuccio M, Edgar R, Federhen S, Feolo LYG, Helberg W, Kapustin Y, Khovayko O, Landsman D, Lipman DJ, Madden TL, Maglott DR, Miller V, Ostell J, Pruitt KD, Schuler GD, Shumway M, Sequeira E, Sherry ST, Sirotkin K, Souvorov A, Starchenko R, Tatusov L, Tatusova TA, et al: Database resources of the National Center for Biotechnology Information. Nucleic Acids Res 2008, 36:D13-21.

59. Altschul SF, Madden TL, Schaffer AA, Zhang J, Zhang Z, Miller W, Lipman DJ: Gapped BLAST and PSI-BLAST: a new generation of protein database search programs. Nucleic Acids Res 1997, 25:3389-3402.

60. Krogh A, Larsson B, von Heijne G, Sonnhammer EL: Predicting transmembrane protein topology with a hidden Markov model: application to complete genomes. J Mol Biol 2001, 305:567-580.

61. Bendtsen JD, Nielsen H, von Heijne G, Brunak S: Improved prediction of signal peptides: SignalP 3.0. J Mol Biol 2004, 340:783-795.

62. Hirokawa T, Boon-Chieng S, Mitaku S: SOSUI: classification and secondary structure prediction system for membrane proteins. Bioinformatics 1998, 14:378-379.

63. Gasteiger E, Hoogland C, Gattiker A, Duvaud Se, Wilkins MR, Appel RD, Bairoch A: Protein identification and analysis tools on the ExPASy server. In The Proteomics Protocols Handbook. Edited by: Walker JM. Totowa: Humana Press; 2005:571-607.

64. Thompson JD, Higgins DG, Gibson TJ: CLUSTAL W: improving the sensitivity of progressive multiple sequence alignment through sequence weighting, position-specific gap penalties and weight matrix choice. Nucleic Acids Res 1994, 22:4673-4680

65. Tamura K, Dudley J, Nei M, Kumar S: MEGA4: Molecular Evolutionary Genetics Analysis (MEGA) software version 4.0. Mol Biol Evol 2007, 24:1596-1599.

66. Ausubel FM, Brent R, Kingston RE, Moore DD, Seidman JG, Smith JA, Struhl K: Current protocols in molecular biology New York: John Wiley \& Sons; 2003.

67. Laemmli UK: Cleavage of structural proteins during the assembly of the head of bacteriophage T4. Nature 1970, 227:680-685.

68. Oh B, Kim H, Lee J, Kang S, Oh T: Staphylococcus haemolyticus lipase: biochemical properties, substrate specificity and gene cloning. FEMS Microbiol Lett 1999, 179:385-392.

69. Westermeier R, Naven T: Proteomics in practice: a laboratory manual of proteome analysis Chichester: Wiley-VCH; 2002.

70. Winkler UK, Stuckmann M: Glycogen, hyaluronate, and some other polysaccharides greatly enhance the formation of exolipase by Serratia marcescens. J Bacteriol 1979, 138:663-670

71. Rhee JK, Ahn DG, Kim YG, Oh JW: New thermophilic and thermostable esterase with sequence similarity to the hormone-sensitive lipase family, cloned from a metagenomic library. Appl Environ Microbiol 2005, 71:817-825.
72. Somers NA, Kazlauskas RJ: Mapping the substrate selectivity and enantioselectivity of esterases from thermophiles. Tetrahedron-Asymmetry 2004, 15:2991-3004.

73. Mateos JC, Ruiz K, Rodriguez JA, Cordova J, Baratti J: Mapping substrate selectivity of lipases from thermophilic fungi. J Mol Catal B: Enzym 2007, 49:104-112.

74. Janes LE, Kazlauskas RJ: Quick E. A Fast Spectrophotometric Method to Measure the Enantioselectivity of Hydrolases. J Org Chem 1997, 62:4560-4561.

75. Tiss $A$, Carriere F, Verger R: Effects of gum arabic on lipase interfacial binding and activity. Anal Biochem 2001, 294:36-43.

doi:10.1186/1475-2859-10-54

Cite this article as: Glogauer et al: Identification and characterization of a new true lipase isolated through metagenomic approach. Microbial Cell Factories 2011 10:54.

\section{Submit your next manuscript to BioMed Central and take full advantage of:}

- Convenient online submission

- Thorough peer review

- No space constraints or color figure charges

- Immediate publication on acceptance

- Inclusion in PubMed, CAS, Scopus and Google Scholar

- Research which is freely available for redistribution 